\title{
EPIDIDYMAL CARBOHYDRATE METABOLISM
}

\author{
III. METABOLISM OF THE GAPUT AND GAUDA EPIDIDYMIDIS \\ AFTER SEPARATION FROM THE TESTIS IN THE RAT
}

\author{
L. A. KRAFT* AND A. D. JOHNSON \\ Department of Animal Science, Livestock-Poultry Building, \\ University of Georgia, Athens, Georgia 30602, U.S.A.
}

(Received 14th Fune 1974)

\begin{abstract}
Summary. After unilateral separation of the rat epididymis from the testis, the metabolism of various substrates in vitro by tissue from the attached and separated caput and cauda epididymidis at 7 and 28 days after surgery was determined by radiorespirometry. Hourly collections of ${ }^{14} \mathrm{CO}_{2}$ were made during 5 -hr incubations. The patterns of ${ }^{14} \mathrm{CO}_{2}$ evolution from glucose indicated that most of the metabolic activity followed the Embden-Meyerhof glycolytic and the Krebs cycle respiration pathways. The alteration of the rate of glycolysis was always greater than that of respiration. In all samples, the metabolism of $\left[2-{ }^{14} \mathrm{C}\right]$ glucose was approximately equal to that of $\left[6-{ }^{14} \mathrm{C}\right]$ glucose $(\mathrm{G}-6)$ and less than that of $\left[1-{ }^{14} \mathrm{C}\right]$ glucose $(\mathrm{G}-1)$. Pentose cycle activity was indicated in all tissues from the caput and cauda epididymidis by the preferential utilization of G-1 over G-6. At 7 and 28 days after surgery, respectively, the G-1:G-6 ratios of ${ }^{14} \mathrm{CO}_{2}$ evolution after incubation for $2 \mathrm{hr}$ were 9.75 and 7.79 for the separated caput, 5.17 and 2.66 for the intact caput, 3.11 and 2.52 for the separated cauda and 3.73 and 2.84 for the attached cauda epididymidis. Although epididymal separation did not affect the metabolism of $\left[\mathrm{U}^{-14} \mathrm{C}\right]$ glucose or $\left[\mathrm{U}^{1}{ }^{14} \mathrm{C}\right]$ fructose, glucose appeared to be a more important epididymal substrate than fructose.
\end{abstract}

\section{INTRODUGTION}

It is well known that passage through the epididymal duct is a very important step in the development of fertile spermatozoa. During this passage, many morphological and physiological alterations of the sperm cell are known to occur (Bishop, 1961; Waites \& Setchell, 1969). Numerous histological and histochemical studies have revealed several regional differences in epididymal epithelial structure and cytochemistry (Reid \& Cleland, 1957; Nicander, 1957; Maneely, 1959; Bishop, 1961 ; Risley, 1963; Martan, 1969). Investigations of epididymal contents have indicated the existence of different environments in these epididymal segments (Crabo, 1965; Gustafsson, 1966), but the cellular

* Present address: Division of Pharmacology, Ortho Research Foundation, Raritan, New Jersey 08869, U.S.A. 
metabolism of the epididymis and comparisons between the various regions have not been extensively studied.

Metabolic studies in the anaesthetized ram (Annison, Scott \& Waites, 1963) have shown glucose to be a more important testicular and epididymal metabolite than acetate. Direct oxidation to $\mathrm{CO}_{2}$ accounted for all of the acetate metabolism, but only $30 \%$ of the glucose utilization. A comparison of anaesthetized and conscious rams by Setchell \& Waites (1964) indicated that 54 and $94 \%$, respectively, of the $\mathrm{O}_{2}$ uptake was utilized for glucose oxidation. Elliott (1965a) found the metabolism of mouse epididymal homogenates in vitro was predominantly glycolytic with a very low oxidative capacity. Similarly, the respiratory activity of tissue from the caput epididymidis of the rabbit has been reported to be lower than that of other mammalian tissues (Wallace, Wales \& White, 1966). Kraft \& Johnson (1972) also found higher rates of glycolysis than respiration in epididymal tissues from rats, mice and rabbits. Patterns of ${ }^{14} \mathrm{CO}_{2}$ evolution from specifically labelled glucose substrates were consistent with the Embden-Meyerhof glycolytic and Krebs cycles as the major pathway of metabolism although some glucose was also metabolized by way of the pentose cycle. Other studies have indicated extensive epididymal pentose cycle activity (Lunaas, Baldwin \& Cupps, 1968; Johnson \& Turner, 1971; Turner \& Johnson, 1973a; Sholl \& Leathem, 1973).

Metabolic activity has also been studied following separation of the epididymis from the testis. Elliott (1965b) reported that efferentiectomy reduced the rate of glycolysis and respiration of mouse epididymal homogenates. The loss of spermatozoa could account for the decreased respiration, but not completely for the lower glycolytic rate indicating a change in the tissue glycolysis. Turner \& Johnson (1973a, b) found a significantly higher utilization of glucose and Krebs cycle intermediates by attached than by separated bull epididymides. Gustafsson (1966) has reported extensive studies on the effects of reduced testicular flow on epididymal function. Changes in the lipid content of separated rat epididymides have been reported (Turner \& Johnson, 1971). These studies indicate that, in addition to adequate androgen levels, many aspects of normal epididymal function appear to depend upon the testicular spermatozoa and/or fluid entering the epididymis.

In this study, a sensitive radiorespirometric procedure was used to measure the metabolism in vitro of specifically labelled glucose and glucose intermediates by tissue from the caput and cauda epididymidis of the rat 7 and 28 days after unilateral separation from the testis.

\section{MATERIALS AND METHODS}

Fourteen mature Wistar rats were anaesthetized with ether and one of the epididymides was separated from the testis through a mid-ventral abdominal incision. The efferent ducts were ligated and then severed, taking care not to disrupt the vascular supply to the testis and epididymis. The complex was returned to the scrotum and the incision closed with silk sutures and metal skin clips. The side to be isolated was randomly selected and the contralateral complex served as the control. 
At 7 and 28 days after surgery, the testes and epididymides were removed and 3 to $6 \mathrm{mg}$ samples of epididymal tissue were prepared and incubated as previously described (Kraft \& Johnson, 1972). The substrates used and their specific activities $(\mu \mathrm{Ci} / \mu \mathrm{mol})$ were: $\left[1-{ }^{14} \mathrm{C}\right]$ glucose $(\mathrm{G}-1), 47 \cdot 8 ;\left[2-{ }^{14} \mathrm{C}\right]$ glucose (G-2), 58.8; $\left[3,4-{ }^{14} \mathrm{C}\right]$ glucose (G-3,4), 13.8; [6- $\left.{ }^{14} \mathrm{C}\right]$ glucose (G-6), 44.9; $\left[\mathrm{U}-{ }^{14} \mathrm{C}\right]$ glucose $(\mathrm{G}-\mathrm{U}), 207 \cdot 0 ;\left[\mathrm{U}-{ }^{14} \mathrm{C}\right]$ fructose $(\mathrm{F}-\mathrm{U}), 121 \cdot 0 ;\left[1{ }^{14} \mathrm{C}\right]$ gluconate, $7 \cdot 23 ;\left[6-{ }^{14} \mathrm{C}\right]$ glucuronate, $2.53 ;\left[1-{ }^{14} \mathrm{C}\right]$ acetate, $55 \cdot 0$. Immediately after inserting the tissue sample, each ampoule was flushed for $30 \mathrm{sec}$ with a gas mixture of $3 \% \mathrm{CO}_{2}, 20 \% \mathrm{O}_{2}$ and $77 \% \mathrm{~N}_{2}$. The rate of $\mathrm{CO}_{2}$ evolution was determined by radiorespirometry by the ampoule system previously described by Turner \& Johnson (1971) and Kraft \& Johnson (1972). Hourly collections of ${ }^{14} \mathrm{CO}_{2}$ (collected in $0.1 \mathrm{ml}$ of diethanolamine buffer) were made during the 5 -hr incubation at $35^{\circ} \mathrm{C}$ in $\mathrm{Krebs}$ Ringer bicarbonate containing amino acids and penicillin in an atmosphere of $3 \% \mathrm{CO}_{2}, 20 \% \mathrm{O}_{2}$ and $77 \% \mathrm{~N}_{2}$. The residual $\mathrm{CO}_{2}$ was collected upon addition of sulphuric acid. After counting in a liquid scintillation spectrometer, the amount of substrate metabolized to $\mathrm{CO}_{2} /$ $\mathrm{mg}$ tissue was calculated after adjustment for counting efficiency $(85 \%)$ and background. The data were subjected to a least squares analysis of variance and Duncan's Multiple Range Test for the determination of significance between means.

Representative tissues were fixed in Bouin's solution and embedded in paraffin wax according to standard techniques. Sections were stained in haematoxylin and eosin.

\section{RESULTS}

At 7 days after surgery, the caput epididymidis was completely devoid of spermatozoa, but the cauda contained motile spermatozoa and appeared similar to the control tissue. By 28 days, the cauda was not yet completely free of spermatozoa, although the quantity was greatly reduced and no motile and many abnormal (separation of the head and tail) spermatozoa were present. The tubule lumen was greatly reduced.

Text-figure 1 shows the respective hourly plus residual recovery rates of ${ }^{14} \mathrm{CO}_{2}$ evolution from each of the specifically labelled glucose substrates during incubation of tissue from attached and separated caput epididymidis 7 days after surgery. Although not shown, similar glucose metabolism was also found in the tissue from the cauda epididymidis and in the caput and cauda tissues at 7 and 28 days after surgery, respectively.

Table 1 shows the G-1:G-6 ratios of ${ }^{14} \mathrm{CO}_{2}$ evolution after incubation for 2 $\mathrm{hr}$. Separation of the epididymis from the testis significantly $(P<0.05)$ increased the proportion of pentose cycle metabolism by the caput epididymidis, but had no effect on the activity of the cauda epididymidis.

The total 5-hr metabolism for each substrate by all the epididymal tissues at 7 and 28 days after surgery is presented in Table 2. Except for the increase in G-1 utilization, no consistent differences in the metabolism of intact and isolated tissues are evident. In all tissues, G-1 metabolism was greater than G-2. Glucose was found to be a more important epididymal substrate than fructose. 


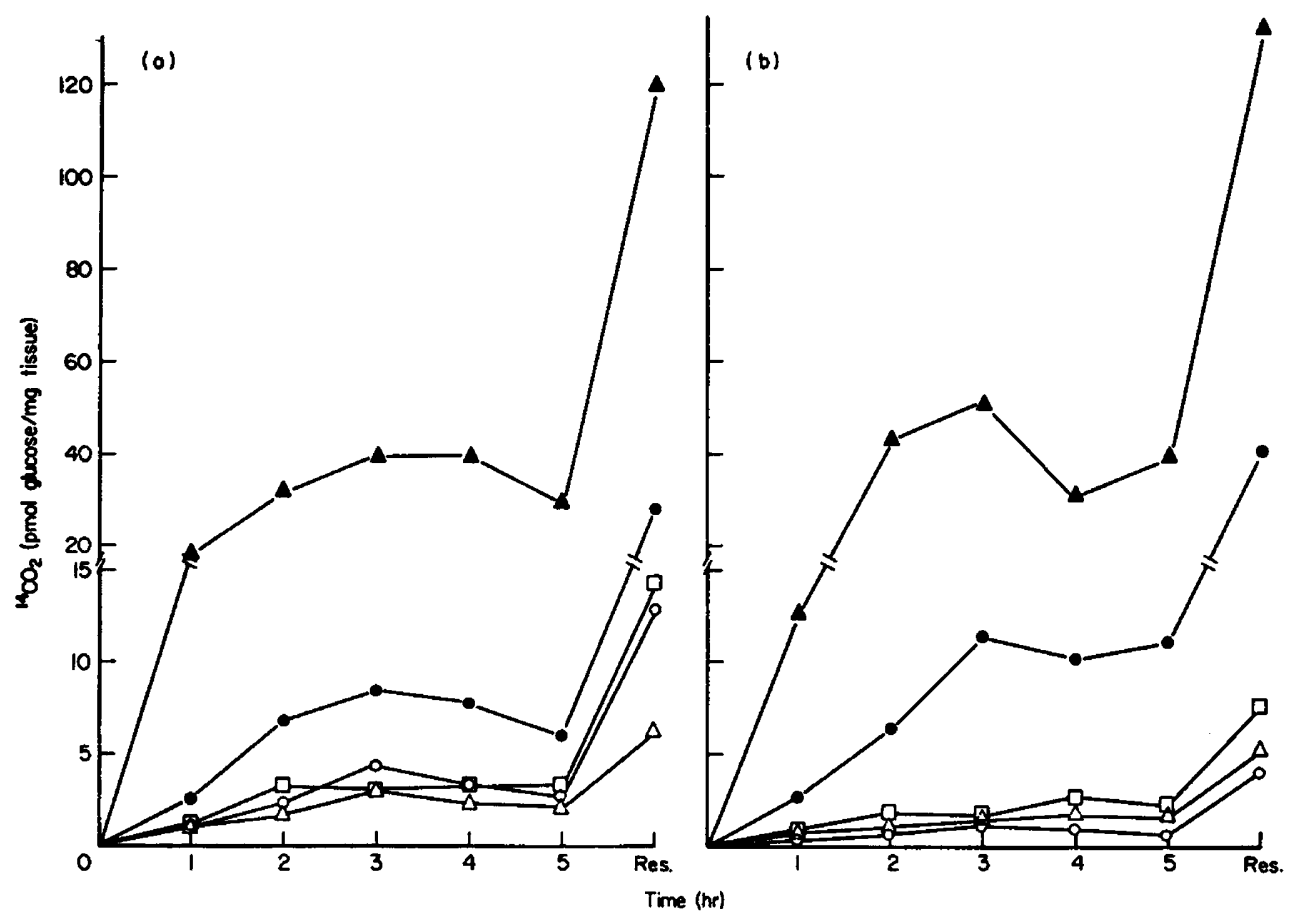

TExT-FIG. 1. The hourly and residual evolution of ${ }^{14} \mathrm{CO}_{2}$ in vitro from specifically labelled glucose substrates by the caput epididymidis of the rat. (a) Attached epididymides; (b) epididymides separated from the testis 7 days previously. Res. $=$ residual. $0,\left[1-{ }^{14} \mathrm{C}\right]-$ glucose; $\square,\left[2-{ }^{11} \mathrm{C}\right]$ glucose; $\Delta,\left[3,4-{ }^{14} \mathrm{C}\right]$ glucose; $O,\left[6-{ }^{14} \mathrm{C}\right]$ glucose; $\Delta,\left[\mathrm{U}-{ }^{14} \mathrm{C}\right]$ glucose.

Table 1. Ratios of the production of ${ }^{14} \mathrm{CO}_{2}$ from $\left[1-{ }^{14} \mathrm{C}\right]$ glucose and $\left[6-{ }^{14} \mathrm{C}\right]$ glucose by epididymal tissues of rats after unilateral separation of the epididymis from the testis

\begin{tabular}{llc}
\hline Time after operation & \multicolumn{2}{c}{ Ratio of $G-1: G-6{ }^{14} \mathrm{CO}_{2}$} \\
\cline { 2 - 3 } & \multicolumn{1}{c}{ Caput } & Cauda \\
\hline 7 days (7 rats) & & \\
Separated epididymis & $9 \cdot 75 \pm 3 \cdot 08^{\mathrm{a}}$ & $3 \cdot 11 \pm 0.48^{\mathrm{c}}$ \\
Attached epididymis & $5 \cdot 17 \pm 1 \cdot 72^{\mathrm{b}, \mathrm{c}}$ & $3 \cdot 73 \pm 1 \cdot 03^{\mathrm{c}}$ \\
28 days (7 rats) & & \\
Separated epididymis & $7 \cdot 79 \pm 1 \cdot 06^{\mathrm{a}, \mathrm{b}}$ & $2 \cdot 52 \pm 0.46^{\mathrm{c}}$ \\
Attached epididymis & $2 \cdot 66 \pm 0.36^{\mathrm{c}}$ & $2 \cdot 84 \pm 0.98^{\mathrm{c}}$ \\
\hline
\end{tabular}

Values are expressed as means \pm S.E.M. Means not followed by the same letter are significantly different $(P<0 \cdot 05)$. 
Table 2. The metabolism of labelled glucose substrates and intermediates by caput and cauda epididymal tissues of rats on Days 7 and 28 after unilateral separation of the epididymis from the testis

\begin{tabular}{|c|c|c|c|c|}
\hline \multirow[t]{2}{*}{ Substrate } & \multicolumn{2}{|c|}{ Separated epididymis } & \multicolumn{2}{|c|}{ Attached epididymis } \\
\hline & Caput & Cauda & Caput & Cauda \\
\hline $\begin{array}{c}\text { Day } 7 \\
{\left[11^{14} \mathrm{C}\right] \text { Glucose }} \\
{\left[2-{ }^{14} \mathrm{C}\right] \text { Glucose }} \\
{\left[3,4^{-14} \mathrm{C}\right] \text { Glucose }} \\
{\left[6-{ }^{14} \mathrm{C}\right] \text { Glucose }} \\
{\left[\mathrm{U}-1^{14} \mathrm{C}\right] \text { Glucose }} \\
{\left[\mathrm{U}-1^{14} \mathrm{C}\right] \text { Fructose }} \\
{\left[1-{ }^{14} \mathrm{C}\right] \text { Gluconate }} \\
{\left[6--^{14} \mathrm{C}\right] \text { Glucuronate }} \\
{\left[1-{ }^{14} \mathrm{C}\right] \text { Acetate }}\end{array}$ & $\begin{array}{c}82 \cdot 0 \pm 10 \cdot 6 \\
17 \cdot 2 \pm 2 \cdot 2 \\
313 \cdot 3 \pm 19 \cdot 9(3) \\
8 \cdot 6 \pm 2 \cdot 0 \\
11 \cdot 3 \pm 1 \cdot 7 \\
3 \cdot 4 \pm 1 \cdot 4 \\
145 \cdot 6 \pm 12 \cdot 2(3) \\
92 \cdot 2 \pm 15 \cdot 4(4) \\
16 \cdot 6 \pm 1 \cdot 9\end{array}$ & $\begin{array}{c}36 \cdot 8 \pm 5 \cdot 7 \\
23 \cdot 2 \pm 2 \cdot 4 \\
\text { N.T. } \\
17 \cdot 6 \pm 3 \cdot 1 \\
15 \cdot 5 \pm 1 \cdot 0 \\
8 \cdot 1 \pm 1 \cdot 7 \\
115 \cdot 0 \pm 13 \cdot 2(3) \\
101 \cdot 9 \pm 10 \cdot 5(4) \\
15 \cdot 6 \pm 2 \cdot 2\end{array}$ & $\begin{array}{c}58 \cdot 9 \pm 7 \cdot 5 \\
28 \cdot 3 \pm 2 \cdot 6 \\
278 \cdot 8 \pm 70 \cdot 5(3) \\
25 \cdot 6 \pm 6 \cdot 6 \\
16 \cdot 6 \pm 1 \cdot 8 \\
6 \cdot 5 \pm 1 \cdot 1 \\
153 \cdot 0 \pm 24 \cdot 3(3) \\
97 \cdot 0 \pm 11 \cdot 7(4) \\
18 \cdot 9 \pm 2 \cdot 4\end{array}$ & $\begin{array}{c}38 \cdot 4 \pm 3 \cdot 1 \\
24 \cdot 2 \pm 3 \cdot 4 \\
\text { N.T. } \\
17 \cdot 2 \pm 2 \cdot 7 \\
19 \cdot 8 \pm 1 \cdot 6 \\
6 \cdot 6 \pm 1 \cdot 4 \\
144 \cdot 1 \pm 11 \cdot 2(3) \\
97 \cdot 5 \pm 5 \cdot 9(4) \\
27 \cdot 2 \pm 8 \cdot 2\end{array}$ \\
\hline 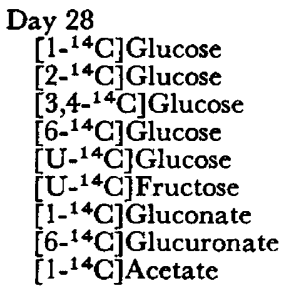 & $\begin{array}{c}74 \cdot 3 \pm 6 \cdot 2 \\
21 \cdot 4 \pm 4 \cdot 9 \\
354 \cdot 0 \pm 48 \cdot 4(4) \\
10 \cdot 3 \pm 2 \cdot 1 \\
15 \cdot 8 \pm 1 \cdot 6 \\
1 \cdot 8 \pm 0 \cdot 2 \\
217 \cdot 1 \pm 66 \cdot 0(3) \\
83 \cdot 3 \pm 15 \cdot 7(4) \\
18 \cdot 6 \pm 2 \cdot 1\end{array}$ & $\begin{array}{c}72 \cdot 8 \pm 7 \cdot 1 \\
31 \cdot 3 \pm 3 \cdot 5 \\
343 \cdot 3 \pm 70 \cdot 5(4) \\
19 \cdot 2 \pm 3 \cdot 5 \\
18 \cdot 2 \pm 2 \cdot 8 \\
4 \cdot 5 \pm 0 \cdot 5 \\
247 \cdot 5 \pm 37 \cdot 9(3) \\
96 \cdot 2 \pm 10 \cdot 5(4) \\
19 \cdot 5 \pm 2 \cdot 0\end{array}$ & $\begin{array}{c}41 \cdot 1 \pm 6 \cdot 5 \\
19 \cdot 0 \pm 2 \cdot 3 \\
369 \cdot 1 \pm 49 \cdot 5(4) \\
13 \cdot 5 \pm 1 \cdot 8 \\
15 \cdot 0 \pm 1 \cdot 8 \\
6 \cdot 7 \pm 0 \cdot 9 \\
136 \cdot 1 \pm 50 \cdot 5(3) \\
79 \cdot 7 \pm 8 \cdot 3(4) \\
28 \cdot 5 \pm 5 \cdot 5\end{array}$ & $\begin{array}{c}39 \cdot 8 \pm 2 \cdot 1 \\
19 \cdot 7 \pm 2 \cdot 3 \\
276 \cdot 8 \pm 64 \cdot 6(4) \\
15 \cdot 6 \pm 2 \cdot 6 \\
15 \cdot 6 \pm 2 \cdot 7 \\
4 \cdot 4 \pm 1 \cdot 5 \\
132 \cdot 7 \pm 19 \cdot 8(3) \\
124 \cdot 3 \pm 14 \cdot 3(4) \\
12 \cdot 5 \pm 1 \cdot 4\end{array}$ \\
\hline
\end{tabular}

Values are expressed as pmol substrate metabolized to ${ }^{14} \mathrm{CO}_{2} / \mathrm{mg}$ tissue/5 hr (means \pm S.E.M.). The numbers in parentheses indicate the number of observations when not equal to 7. N.T. $=$ not tested.

\section{DISCUSSION}

These data indicate that the patterns of ${ }^{14} \mathrm{CO}_{2}$ evolution from attached and separated rat epididymal tissues were similar at 7 and 28 days after surgery. The recovery of $\mathrm{CO}_{2}$ from G-3,4 predominated, followed by recovery from G-1 and then G-2 and G-6. These patterns of ${ }^{14} \mathrm{CO}_{2}$ evolution from glucose indicate that most of the metabolic activity followed the Embden-Meyerhof glycolytic and the Krebs cycle respiration pathways and are consistent with previous reports of epididymal (Kraft \& Johnson, 1972; Turner \& Johnson, 1973a) and testicular (Free \& VanDemark, 1969) tissue metabolism. The high ${ }^{14} \mathrm{CO}_{2}$ evolution from G-3,4 indicated that the rate of glycolysis always exceeded that of respiration.

The metabolism of G-2 was less than that of G-1 in all tissues examined. Turner \& Johnson (1973a) obtained similar results from bovine epididymal tissue, although Kraft \& Johnson (1972) found that G-2 metabolism always exceeded utilization of G-1 in rat, rabbit and mouse tissues. Although other substrates were generally comparable, the metabolism of G-2 reported here is approximately $25 \%$ of that found previously. No explanation for this difference is apparent.

Preferential utilization of G-1 over G-6 was evident in all tissues from the caput and cauda epididymidis, and indicates extensive metabolism by the pentose cycle since a G-1:G-6 ratio $>1$ is characteristic of activity in this pathway. Separation of the epididymis significantly $(P<0.05)$ increased the 
G-1:G-6 ratios in caput tissues, but had no effect on the cauda tissues. This change in caput tissue metabolism was similar at 7 and 28 days after operation. This suggests that the constituents of the fluid from the testis influence the metabolism in the caput epididymidis or that spermatozoa in this area are metabolically different from the epididymal tissue. By comparing results on Day 7 with those on Day 28 (Table 1), it is evident that activity by way of the pentose cycle decreases with time. This decreased pentose cycle activity may be associated with altered lipid, nucleic acid, or NADPH metabolism. Previous reports indicate numerous functional and environmental changes within the separated epididymis (Gustafsson, 1966; Waites \& Setchell, 1969; Turner \& Johnson, 1971). Although Turner \& Johnson (1973a) reported extensive pentose cycle activity in bovine epididymal tissue, no increase in metabolism resulted following separation. No significant differences in G-1:G-6 ratios were found between the attached caput and cauda tissues in this study, confirming previous results (Johnson \& Turner, 1971; Kraft \& Johnson, 1972) for the rat.

The histology of the separated epididymis was similar to that described by Turner \& Johnson (1971), except that these workers found the cauda completely devoid of spermatozoa by 21 days after surgery and in this study many spermatozoa were still present at 28 days. None of these spermatozoa, however, appeared to be viable; many were decapitated and no motility was observed. Although epididymal separation resulted in a sharp decrease in epididymal size and tubular diameter, the epithelium appeared normal. Others have reported normal histology of the isolated epididymis except sometimes in the initial portion of the caput (Gustafsson, 1966; Turner \& Johnson, 1971; Turner \& Johnson, 1973a).

Efferentiectomy has been reported to cause a decrease in the epididymal tissue metabolism of the mouse (Elliott, 1965b) and bull (Turner \& Johnson, 1973a, b). Much of this decrease was attributed to loss of spermatozoa, but a change in the rate of tissue metabolism was also contributory. In contrast, separation of the rat epididymis in this study did not reduce the metabolic rate of the epididymal tissue at either 7 or 28 days after surgery. These results suggest that the rat epididymal tissues and spermatozoa have similar rates of glucose metabolism, at least in vitro. The metabolic contribution of the spermatozoa remaining after 28 days in the separated cauda epididymidis was not determined, but was presumably minor in view of the lack of sperm motility and abnormal sperm morphology. On the other hand, it is possible that the sperm contribution to total epididymal metabolic rate is less in the rat than in the bull or mouse, thus making a decrease after efferentiectomy less apparent. Although the utilization of G-U and F-U was not changed by epididymal separation, glucose was a more important epididymal substrate than fructose. Turner \& Johnson (1973a) also found this in the bovine epididymis. It is evident that fluids of the testis or the presence of spermatozoa in the caput epididymidis alter to some extent the use of the pentose cycle, at least in vitro.

\section{REFERENCES}

Annison, E. F., ScotT, T. W. \& Wartes, G. M. H. (1963) The role of glucose and acetate in the oxidative metabolism of the testis and epididymis of the ram. Biochem. 7. 88, 482-488. 
Bishop, D. W. (1961) Biology of spermatozoa. In Sex and Internal Secretions, 3rd edn, Vol. II, pp. 707-796. Ed. W. C. Young. Williams \& Wilkins, Baltimore.

GrABo, B. (1965) Studies on the composition of epididymal content in bulls and boars. Acta vet. scand. Suppl. 5.

Elliotr, P. R. (1965a) Metabolism of homogenates of the mouse epididymis. F. cell. comp. Physiol. 66, 281-292.

ELLIOTT, P. R. (1965b) Effect of efferentiectomy and orchidectomy on the metabolism of the epididymis of the mouse. F. cell. comp. Physiol. 66, 293-301.

Free, M. J. \& VANDemark, N. L. (1969) Radiorespirometric studies on glucose metabolism in testis tissue from rat, rabbit and chicken. Comp. Biochem. Physiol. 30, 323-333.

Gustafsson, B. (1966) Luminal contents of the bovine epididymis under conditions of reduced spermatogenesis, luminal blockage and certain sperm abnormalities. Acta vet. scand. Suppl. 17.

Johnson, A. D. \& TURNer, P. C. (1971) Epididymal carbohydrate metabolism. I. Glucose-1 $1{ }^{14} \mathrm{C}$ and glucose-6- ${ }^{14} \mathrm{C}$ metabolism by mouse, rat and rabbit tissues. Comp. Biochem. Physiol. 39A, 599-604.

Kraft, L. A. \& Johnson, A. D. (1972) Epididymal carbohydrate metabolism. II. Substrates and pathway utilization of caput and cauda epididymal tissue from the rabbit, rat and mouse. Comp. Biochem. Physiol. 42B, 451-461.

Lunaas, T., Baldwin, R. L. \& Gupps, P. T. (1968) Level of certain soluble dehydrogenases in the rat testis and epididymis. F. Reprod. Fert. 17, 177-178.

Maneely, R. B. (1959) Epididymal structure and function, a critical review. Acta zool. 40, 1-21.

Martan, J. (1969) Epididymal histochemistry and physiology. Biol. Reprod. Suppl. 1, 134-154.

NicANDER, L. (1957) On the regional histology and cytochemistry of the ductus epididymidis in rabbits. Acta morph. neerl.-scand. 1, 99-118.

Reid, B. L. \& Cireland, K. W. (1957) The structure and function of the epididymis. I. The histology of the rat epididymis. Aust. F. Zool. 5, 223-246.

Ristey, P. L. (1963) Physiology of the male accessory organs. In Physiological Mechanisms Concerned with Conception, pp. 73-133. Ed. C. G. Hartman. Pergamon Press, New York.

Setchell, B. P. \& Wartes, G. M. H. (1964) Blood flow and the uptake of glucose and oxygen by the testis and epididymis of the ram. F. Physiol., Lond. 171, 411-425.

Sholl, S. A. \& LzATHEM, J. H. (1973) Effects of postnatal maturation and castration on rat epididymal carbohydrate metabolism. Proc. Soc. exp. Biol. Med. 142, 635-637.

Turner, P. C. \& Johnson, A. V. (1971) Epididymal lipid of the rat with and without testicular contribution. F. Reprod. Fert. 27, 249-255.

TURner, T. T. \& Johnson, A. D. (1973a) The metabolic activity of the bovine epididymis. I. Utilization of glucose and fructose. F. Reprod. Fert. 34, 201-213.

Turner, T. T. \& Johnson, A. D. (1973b) The metabolic activity of the bovine epididymis. II. Utilization of acetate, succinate, pyruvate, lactate and glucose. F. Reprod. Fert. 35, 445-451.

Wartes, G. M. H. \& Setchell, B. P. (1969) Physiology of the testis, epididymis and scrotum. Adv. Reprod. Physiol. 4, 1-63.

Wallace, J. C., Wales, R. G. \& White, I. G. (1966) Respiration of the rabbit epididymis and its synthesis of glycerylphosphorylcholine. Aust. F. biol. Sci. 19, 849-856. 